\title{
Evolution of the Serotypes of Aggregatibacter actinomycetemcomitans In Relation to Aggressive Periodontitis and Geographic Origin of Individuals - A Review of the Literature
}

ISSN: 2637-7764

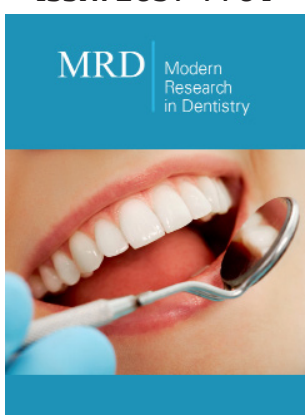

${ }^{* 1}$ Corresponding author: CChi Cheng Tsai, Chung Shan Medical University, Taiwan

Submission: 眥January 08, 2019

Published: 㘹 March 13, 2019

Volume 3 - Issue 5

How to cite this article: Chi Cheng $\mathrm{T}$, Ying Chu L. Evolution of the Serotypes of Aggregatibacter actinomycetemcomitans in Relation to Aggressive Periodontitis and Geographic Origin of Individuals- A Review of the Literature. Mod Res Dent. 3(5). MRD.000572.2019.

DOI: 10.31031/MRD.2019.03.000572

Copyright@ Chi Cheng Tsai, This article is distributed under the terms of the Creative Commons Attribution 4.0 International License, which permits unrestricted use and redistribution provided that the original author and source are credited.

\author{
Chi-Cheng Tsai ${ }^{1 *}$ and Ying-Chu Lin ${ }^{2}$ \\ ${ }^{1}$ School of Dentistry, Chung Shan Medical University, Taiwan \\ ${ }^{2}$ College of Dental Medicine, Kaohsiung Medical University, Taiwan
}

\begin{abstract}
Background: Researchers have investigated the relationship among serotype distribution, ethnical status and geographic populations, and periodontal conditions. Studies that have examined the prevalence and the distribution of A. actinomycetemcomitans (A.a.) serotypes and the relation between the different serotypes of the bacterium and periodontal status were reviewed.
\end{abstract}

Material and methods: A systemic literature search for publications in the database PubMed between 1983 and January 2018 regarding the distribution of A.a. serotypes in subgingival samples of periodontitis patients and periodontally healthy subjects by various techniques (including culture, immunodiffusion, immunofluorence, polymerase chain reaction was carried out.

Results: From the cited studies, A.a. bacteria were isolated from various periodontal conditions, including aggressive periodontitis. Clinical isolates from diverse geographic populations with different periodontal conditions were summarized. Serotypes a, b and c were largely found, and serotype c was the most prevalent. The distribution of the most recently identified serotype g remains unknown.

Conclusion: The current literature reviews suggest that serotype a, b, and c are universally dominant, serotypes $\mathrm{d}, \mathrm{c}$ and $\mathrm{f}$ are rare; the distribution of the most recently identified serotype $\mathrm{g}$ still needs more studies to provide its distribution and its effect on periodontitis. It is widely accepted that distribution patterns of A.a. vary among subjects of different ethnicity and geographic regions. The importance of the identification of A.a. and their antibiotic susceptibility tests prior to the treatments of periodontitis especially for aggressive periodontitis and peri-implantitis concomitantly to periodontal therapy are strongly advised.

Keywords: Aggregatibacter actinomycetemcomitans (A.a.); Serotypes; Aggressive periodontitis (AgP); Periodontal diseases; Prevalence

\section{Introduction}

Aggressive periodontitis is a severe and rapidly progressing form of periodontitis [1,2] that affecting supporting tissues of the teeth induced by microbial deposits [3]. Aggregatibacter actinimycetemcomitans is an important pathogen related to aggressively progressive periodontal breakdown in adolescents and adults [4,5]. A. actinomycetemcomitans (A.a.) can be grouped into seven serotypes (a-g) [6,7]. Several studies have examined the relationship of A.a. serotype, ethnical status and geographic populations, periodontal disease status $[8,9,10]$. Individuals are usually colonized by a single serotype that can exist for life $[8,11,12]$. The frequency distribution of $A$.a. serotypes differs among various populations [13]. The available literature suggests that serotypes a, b. and c occur much more often among oral isolates than $\mathrm{d}, \mathrm{e}, \mathrm{f}$ and $\mathrm{g}[14,15,16]$. The serotype distributions have been shown to be different among various geographic populations including African, Asian, Europeans, and North and South American $[15,16,17,18,19]$. The purpose of the present study was to review the studies that have investigated the prevalence and the distribution of A.a. serotypes in subgingival samples 
of periodontitis (especially the aggressive periodontitis) patients and to examine the possible evolution of the serotypes.

\section{Materials and methods}

\section{Data sources}

The electronic database PubMed was searched systemically for studies published between 1983 and January 2018. The search terms included "serotypes" and "Aggregatibacter actinomycetemcomitans" or "Acticbacillus actinomycetemcomitans" and "periodontitis".

\section{Study selection}

Studies involving the distribution of A.a. serotypes in subgingival samples of periodontitis patients and periodontally healthy subjects by employing culture, indirect immunofluorescence and/ or immunodiffusion assays, and polymerase chain reaction (PCR) were eligible for inclusion in this review. Data were extracted from each study:

(a) the first author and year of publication; (b) the country where the study was investigated;

(c) searched serotypes and

(d) possible association between periodontal conditions and serotypes.

\section{Result}

Forty-two articles were identified. The full text/abstract of each of the 42 papers was reviewed. The study selections are presented in Table 1. The publication dates ranged from 1983 to 2018. Clinical isolates from diverse geographic populations with different periodontal conditions were evaluated. The samples were obtained of the subjects from Brazil, Germany, Greece, Indonesia, Japan, Korea, Taiwan, Thailand and United States (US) etc. Table 1 shows the prevalence and distribution of A.a. serotypes a, b and c were largely found, and serotype c was the most prevalent. These serotypes were isolated from various periodontal conditions, including aggressive periodontitis. Serotypes d, e, f and g were either not detected or were relatively infrequent. Some A.a. isolates were non-typed.

Table 1: Prevalence and distribution of A. actinomycetemcomitans (A.a.) serotypes and association with periodontal status. LAgP: Localized Aggressive Periodontitis. CP: Chronic Periodontitis, JP: Juvenile Periodontitis.

\begin{tabular}{|c|c|c|}
\hline Study/Country & Occurrence of $A . a$. Serotypes & Periodontal Conditions and Serotypes \\
\hline $\begin{array}{l}\text { Zambon } 1983[8] / \\
\text { US }\end{array}$ & $\begin{array}{l}\text { A total of } 301 \text { isolates of A.a. from the oral cavity of } 74 \text { sub- } \\
\text { jects }\end{array}$ & $\begin{array}{l}\text { Each patient harbored only one serotype. Fourteen healthy } \\
\text { subjects and } 7 \mathrm{CP} \text { patients exhibited serotypes a and b in } \\
\text { almost equal frequency, c was less frequently. In } 29 \mathrm{LAgP} \\
\text { patients, the number of patients with b serotype were } 2 \text { folds } \\
\text { higher than that of serotypes a or c, suggesting a particular } \\
\text { high periodontopathic potential of A.a. serotypes b strains. }\end{array}$ \\
\hline $\begin{array}{l}\text { Zambon et al. } 1983 \\
\qquad[11] / \text { US }\end{array}$ & $\begin{array}{l}\text { A.a. was in } 28 \text { of } 29 \mathrm{LAgP} \text { patients but only } 15 \% \text { of the other } \\
\text { subjects ( } 29 \text { of } 134 \mathrm{CP} \text { patients), } 24 \text { of } 142 \text { periodopntally } \\
\text { healthy subjects. Individuals within a family all harbored the } \\
\text { same serotype. }\end{array}$ & $\begin{array}{c}\text { The high prevalence of A.a. in the sub- gingival plaque of LAgP } \\
\text { patients, compared to the much lower prevalence in other } \\
\text { patient groups supports the hypothesis that A.a. is an etiologic } \\
\text { agent in AgP (JP). }\end{array}$ \\
\hline $\begin{array}{l}\text { Zambon } 1985[20] / \\
\text { US }\end{array}$ & Serotype of A.a. has been categorized into 3 serotypes. & $\begin{array}{l}\text { A.a. as an important microorganism in the etiology of LAgP } \\
\text { (LJP). }\end{array}$ \\
\hline $\begin{array}{l}\text { Tsai et al. } 1987 \\
\text { [21]/ Taiwan }\end{array}$ & $\begin{array}{l}\text { Immunodiffusion data indicated that greater than } 60 \% \text { of AgP, } \\
\text { advanced destructive patients reacted to antigens found in the } \\
\text { A.a. (mainly to serotype c or strain } 652 \text { ). }\end{array}$ & $\begin{array}{l}\text { The periodontal destruction in Chinese periodontitis patients } \\
\text { especially JP and ADP are associated with infection by and } \\
\text { immune response to A.a. }\end{array}$ \\
\hline $\begin{array}{c}\text { Chung et al. } 1989 \\
\text { [22]/ Korea }\end{array}$ & $\begin{array}{l}\text { A.a. occurred in } 75 \% \text { of LJP lesions and } 6 \% \text { of normal sites } \\
\text { with approximately equal distribution of serotype a, b, and } \\
\text { c. Single serotypes were isolated from } 9 \text { patients while } 3 \\
\text { patients harbored } 2 \text { serotypes either in the same or different } \\
\text { disease sites. A.a. leukotoxicity occurred in } 22 \% \text { isolates with } \\
\text { a } 62 \% \text { prevalence. Individual sites harbored both leukotoxic } \\
\text { and non-leukotoxic strains of A.a. with no serotype associa- } \\
\text { tion. }\end{array}$ & $\begin{array}{l}\text { The distribution of serotypes and leuko- toxic strains of A.a. } \\
\text { in Korean LJP patients differed from those reported in the US. } \\
\text { This suggests that serotype b may not be more important in the } \\
\text { pathogenesis of LJP. }\end{array}$ \\
\hline $\begin{array}{l}\text { Asikalinen et al. } \\
1991 \text { [23]/Finland }\end{array}$ & $\begin{array}{l}\text { All } 3 \text { seropes (a, b, c) were commonly found. Serotype b was } \\
\text { dominant in subjects with periodontal disease and serotype c } \\
\text { was the most common serotype in the healthy subjects. }\end{array}$ & $\begin{array}{l}\text { This study suggests differences in the distri- bution of A.a. } \\
\text { serotypes between periodontal health and disease. }\end{array}$ \\
\hline
\end{tabular}




\begin{tabular}{|c|c|c|}
\hline $\begin{array}{l}\text { Saarela et al. } 1992 \\
\text { [24]/Finland }\end{array}$ & $\begin{array}{l}86 \text { subjects ( } 95 \%) \text { : one serotype only, } 466 \text { ( } 91 \% \text { ) isolates } \\
\text { from } 80 \text { subjects were serotype a ( } 25 \% \text { of isolates/30 sub- } \\
\text { jects), b ( } 25 \% \text { of isolates } / 27 \text { subjects), c ( } 41 \% \text { of isolates/30 } \\
\text { subjects), d ( } 15 \text { isolates/4 subjects), e ( } 18 \text { isolates } / 5 \text { subject), } \\
\text { untypable ( } 16 \text { isolates } / 5 \text { subjects). } 1 \text { to } 6 \text { years followed: } \\
\text { same infected serotypes, stability of infected serotypes was } \\
\text { demonstrated. }\end{array}$ & $\begin{array}{l}1 \text { to } 6 \text { years followed up: same infected serotypes stability of } \\
\text { infected A.a. was demonstrated. }\end{array}$ \\
\hline $\begin{array}{l}\text { Yamamoto et al. } \\
1997[25] / J a p a n\end{array}$ & $\begin{array}{l}\text { A total of } 157 \text { A.a. isolates from } 39 \text { patients with periodontitis: } \\
\text { Serotypes: } 42 \text { (a), } 6 \text { (b), } 39 \text { (c), } 9 \text { (d), } 41 \text { (e), } 20 \text { (untypable). }\end{array}$ & $\begin{array}{l}37 \text { patients are with single serotype, } 2 \text { patients with } 2 \text { different } \\
\text { serotype strains (b/e, b/untypable) which were identical to } \\
\text { that A.a. Y4 (serotype). Conclusion: The presence of multiple } \\
\text { A.a. serotypes. }\end{array}$ \\
\hline $\begin{array}{c}\text { Mombelli et al. } 1998 \\
\text { [26]/China }\end{array}$ & $\begin{array}{c}\text { A.a.- }(+): 37 / 60 \text { subjects. } 21 \text { subjects: }(+) \text { for both } A . a . \text { and P.g.. } \\
\text { Serotypes: a }(9,24.32 \%), \mathrm{c}(23,62.16 \%), \mathrm{e}(5,13.51 \%), \mathrm{b}, \mathrm{d} \text {, } \\
(0,0 \%) .\end{array}$ & $\begin{array}{l}\text { The results show a high frequency of the putative periodontal } \\
\text { pathogens P.g. and A.a. and corroborate the concept that there } \\
\text { is variation in virulence and pathogenic potential among iso- } \\
\text { lates from different subjects. }\end{array}$ \\
\hline $\begin{array}{l}\text { Mombelli et al. } 1999 \\
\text { [27]/China }\end{array}$ & $\begin{array}{c}\text { 117/185(63.24\%) subjects were } A . a-(+) \text { All } 115 \text { isolates were } \\
\text { leukotoxin gene IktA. Serotyes: a }(21,17.0 \%), \mathrm{b}(9,7.6 \%) \text {, c } \\
(67,57.3 \%), \text { e }(11,9.40 \%), \mathrm{d}(0,0 \%) \text {, non-typed }(9,9.4 \%) \text {. }\end{array}$ & $\begin{array}{l}\text { A high prevalence irrespective of gender, and cohort suggests } \\
\text { that } \text { A.a. is a common constituent of the normal flora and } \\
\text { suggests differences in the microbial composition of subgingial } \\
\text { plaque may exist for this population group as compared to } \\
\text { north American and European populations. }\end{array}$ \\
\hline $\begin{array}{l}\text { Saarela et al. } 1999 \\
\text { [28]/Finland }\end{array}$ & $\begin{array}{l}922 \text { A.a. isolates from } 115 \text { subjects. Followed-up for } 0.5 \text { to } \\
11.5 \text { yrs. } 99 \text { subjects were treated. } 104 \text { subjects with only one } \\
\text { serotype, or non-typeable isolates: a ( } 25 \%), \text { b ( } 33 \%), \text { c ( } 23 \%) \text {, } \\
\text { d ( } 5 \%), 2 \text { (7\%), non-typeable ( } 8 \%) \text {. } 2 \text { serotypes in } 9 \text { subjects } \\
\text { were detected at sampling occasion. } 1 \text { subject: initial serotype } \\
\text { was not recovered, a different serotype was once seen alone. } 1 \\
\text { subject: initial serotype was not recovered later. }\end{array}$ & $\begin{array}{c}\text { Identical genotypes of A.a. were repeatedly detected in each } 52 \\
\text { subjects followed up isolates were the same serotypes. }\end{array}$ \\
\hline $\begin{array}{l}\text { Kaplan et al. } 2001 \\
\text { [29]/US }\end{array}$ & $\begin{array}{l}\text { A PCR assay using serotype-specific PCR primers showed } \\
\text { that3 out of } 20 \text { LJP patients surveyed (15\%) harbored A.a. } \\
\text { strains carrying the serotype f gene cluster. }\end{array}$ & New serotype f was reported. \\
\hline $\begin{array}{l}\text { Dahlen et al. } 2002 \\
\text { [30]/Thailand }\end{array}$ & $\begin{array}{l}\text { A.a.-(+): 53/60 (88\%) subjects, } 11 \text { subjects harbored } 2 \text { or } 3 \\
\text { different strains. Serotypes a and c were the most prevalent, } \\
\text { and serotype b was found only once among } 46 \text { tested isolates. }\end{array}$ & $\begin{array}{l}\text { Tis study demonstrated a high prevalence of A.a. among adults } \\
\text { of the rural population of south Thailand and indicates that. } \\
\text { A.a. present as part of the resident flora in this population. }\end{array}$ \\
\hline $\begin{array}{l}\text { Yoshida et al. } 2003 \\
\text { [31]/Japan }\end{array}$ & $\begin{array}{l}\text { Among } 328 \text { subjects: A.a.-(+) in } 19.5 \% \text {, P.g. }(+): 27.1 \% .39 / 75 \\
\text { A.a. positive sites ( } 52 \%) \text { with only one serotype. Sites with } 2 \\
\text { and } 3 \text { different serotypes were } 18 \text { and } 7(9.3 \%) \text { respectively. } \\
\text { A.a. serotype[i] c was detected more often ( } 76.9 \%) \text { in sites } \\
\text { that were positive for both P.g. and A.a. than in sites that were } \\
\text { only A.a.-positive (33\%). }\end{array}$ & $\begin{array}{l}\text { The distribution of A.a. serotypes serotype was influenced by } \\
\text { the presence of P.g.. The results suggest that the characteristic } \\
\text { of serotype c may differ from those the other serotypes. }\end{array}$ \\
\hline $\begin{array}{l}\text { Yang et al. } 2004 \\
\text { [32]/US }\end{array}$ & $\begin{array}{c}115 \text { (33 AgP, } 82 \mathrm{CP}) / 345 \text { subjects were A.a.-(+). } 86.96 \% \text { of } \\
\text { subjects with a single serotype ( } 22 \text { a, } 44 \text { b, } 30 \text { c, } 1 \text { d, } 3 \text { e), } 11 \\
(9.57 \%) \text { with } 2 \text { serotypes, } 2 \text { (1.74\%) with } 3 \text { serotypes, } 2 \text { with } \\
\text { no detectable antigen. }\end{array}$ & $\begin{array}{l}\text { The proportions of serotype b of A.a. are significantly greater } \\
\text { in culture- }(+) \text { patients with AgP than those with CP (b serotype } \\
\text { was predominant in age under } 18 \text { yrs. and between 19-35yrs } \\
\text { old, but were not in age older than } 35 \text { years. } 62 \text { adult patients: } \\
\text { one with d, } 3 \text { with e. Serotype b as the most common in AgP } \\
(60.61 \%) \text {. The proportion of subjects with serotype b was sig- } \\
\text { nificantly higher in AgP compared to CP. Other serotypes were } \\
\text { not significantly associated with new diagnostic categories. } \\
\text { Serotypes d and e were not detected in AgP patients. }\end{array}$ \\
\hline $\begin{array}{l}\text { Yang et al. } 2005 \\
\text { [15]/Taiwan }\end{array}$ & $\begin{array}{c}171 \text { subjects (70 AgP, } 101 \mathrm{CP}, 50 \mathrm{HC}) \text {. A.a.-(+): } 84.3 \% \text { in } \mathrm{AgP} \text {, } \\
60.4 \% \text { in } \mathrm{CP}, 64.0 \% \text { in } \mathrm{HC} .\end{array}$ & $\begin{array}{l}\text { The results suggest that prevalence and pro portions of A.a. } \\
\text { are significantly greater in AgP patients than in those with CP. } \\
\text { Serotype b is the predominant serotype of A.a. in patient with } \\
\text { diseased periodontal conditions. Serotype c is a more common } \\
\text { serotype detected in periodontal healthy subjects (HC). }\end{array}$ \\
\hline
\end{tabular}




\begin{tabular}{|c|c|c|}
\hline $\begin{array}{c}\text { Teixeira et al. } 2006 \\
\text { [33]/Brazil }\end{array}$ & $\begin{array}{l}146 \text { isolates from } 23 \text { patients (AgP or } \mathrm{CP} \text { ) and } 26 \text { specimens } \\
\text { from subjects with or without periodontitis serotypes b and c } \\
\text { were observed in similar frequencies, no subject harbored d, } \\
\text { e or f serotype. } 78 \% \text { with single serotype, } 1 \mathrm{AgP} \text { with mixed } \\
\text { serotypes. }\end{array}$ & $\begin{array}{l}\text { An association between serotype } \mathrm{b} \text { and healthy periodontium } \\
\text { and between serotype } \mathrm{c} \text { and } \mathrm{CP} \text { was observed. }\end{array}$ \\
\hline $\begin{array}{l}\text { Fine et al. } 2007 \\
\qquad[34] / \text { US }\end{array}$ & $\begin{array}{c}\text { 1.2\% LJP schoolchildren: } 13.7 \% \text { carried A.a. (16.7\% of African } \\
\text { and } 22 \% \text { of Hispanic students) A.a. serotypes a, b, and c were } \\
\text { equally distributed among African-Americans; Hispanic stu- } \\
\text { dents harbored predominantly serotype c. }\end{array}$ & $\begin{array}{l}\text { Detection of A.a. in periodontally healthy children can serve } \\
\text { as a risk marker for initiation of LAP. (Students without A.a. at } \\
\text { baseline had a significantly greater chance to remain healthy } \\
\text { compared to the A.a.-positive test-group and none of } 58 \\
\text { A.a.-negative students showed bone loss. survival (healthy) }\end{array}$ \\
\hline $\begin{array}{c}\text { Thiba et al. } 2007 \\
\text { [35]/Japan }\end{array}$ & $\begin{array}{l}32 \text { GCP, } 16 \text { GAgP and } 8 \text { LAgP patients. A.a.-(+): LAgP (53\%), } \\
\text { GAgP (38\%), CP (16\%). Serotype c was detected in 50\% of } \\
\text { LAgP patients. }\end{array}$ & $\begin{array}{l}\text { Serotype } \mathrm{c} \text { is predominant A.a. serotype in Japanese LAgP } \\
\text { patients. }\end{array}$ \\
\hline $\begin{array}{l}\text { Van der Reijden } \\
\text { et al. } 2008[36] / \\
\text { Indonesia }\end{array}$ & $\begin{array}{l}\text { In } 1994 \text { subjects with A.a.-(+) serotype: b (53.7\%), a (17.1\%), } \\
\text { c (14.6\%), e (2.4\%), multiple serotypes (12.2\%); in 2002: } \\
\text { a (7.5\%), b (30.2), c ( } 35.8 \%) \text {, e (9.4\%), Multiple serotypes } \\
\text { (17\%). From } 24 \text { subjects who were positive serotypes both } \\
\text { in } 1994 \text { \& } 2002: 14 \text { ( } 58.3 \%) \text { had had the same serotype, } 10 \\
\text { subjects (41.7\%) with different serotype. }\end{array}$ & $\begin{array}{l}\text { Subgingival presence of A.a., but not a specific serotype is asso- } \\
\text { ciated with a higher degree of inflammation. A.a. serotypes dis- } \\
\text { tribution in Indonesia young adults shifts from predominantly } \\
\text { serotype b to a more equal prevalence of serotypes b and c. }\end{array}$ \\
\hline $\begin{array}{l}\text { Kim et al. } 2009 \\
\text { [37]/ Korea/Ger- } \\
\text { many }\end{array}$ & $\begin{array}{l}194 \text { patients ( } 96 \text { Germans, } 98 \text { Koreans) with AgP or severe CP. } \\
\text { Serotypes a through f were tested. A.a.-(+): Germans (27.0\%), } \\
\text { Koreans (22.2\%). In Germans: b (33.3\%, c (25.0\%), a (20.8\%). } \\
\text { In Koreans: c (61.9\%), d (19.0\%). }\end{array}$ & $\begin{array}{l}\text { The distribution of A.a. serotypes may exhibit marked differ- } \\
\text { ences. }\end{array}$ \\
\hline $\begin{array}{l}\text { Kawamoto et al. } \\
2009 \text { [38]/Brazil }\end{array}$ & $\begin{array}{l}\text { A.a. serotypes: c (68.0\%), b: from AgP, high leukotoxin pro- } \\
\text { duction. } 57.1 \% \text { of a serotype: low toxicity to Chinese hamster } \\
\text { ovary (CHO) cells. Serotypes b and c were highly toxic strains. }\end{array}$ & $\begin{array}{l}\text { Differences in prevalence of the low and highly cytotoxic } \\
\text { strains among serotypes reinforce the hypothesis that serotype } \\
\mathrm{b} \text { and c isolates of } A \text {.a. are more virulent than serotype b strain. }\end{array}$ \\
\hline $\begin{array}{l}\text { Hoglund Aberg et al. } \\
2009[39] / \text { Sweden }\end{array}$ & $\begin{array}{l}\text { Serotypes a-c ad e, but not d or f, were detected from the } 14 \\
7 \text { - } 9 \text { yrs- old subjects at the baseline examination. Among the } \\
\text { isolates from the } 6 \text { A.a. positive young adults, serotypes a-c, } \\
\text { and f were identified. }\end{array}$ & $\begin{array}{l}\text { The presence of } A . a \text {. and early bone loss in the primary denti- } \\
\text { tion does not necessary predispose the individual to periodon- } \\
\text { tal attachment loss in the permanent dentition. }\end{array}$ \\
\hline $\begin{array}{l}\text { Roman-Torres et al. } \\
2010[40] / \text { Brazil }\end{array}$ & $\begin{array}{l}\text { A.a. - (+): In } 85 / 486 \text { (17.5\%) subjects, } 68 \text { were infected by } \\
\text { at least } 1 \text { serotype, } 7 \text { by mixed, and } 10 \text { were non-serotyped. } \\
\text { Serotypes } d \text { and f were not detected. Serotype c showed the } \\
\text { highest prevalence }(52.9 \%) \text {, followed by a ( } 31.8 \%) \text {. }\end{array}$ & $\begin{array}{l}\text { The prevalence of serotype } c \text { in severe periodontitis was sig- } \\
\text { nificantly greater than that of serotypes of } a \text { and } b .\end{array}$ \\
\hline Chen 2010 [41]/US & $\begin{array}{l}161 \text { subjects to give } 82 \text { isolate. Serotypes: a }(21,25.6 \%), \mathrm{b} \\
(12,14.6 \%), \text { c }(41,50 \%) \text {, e }(6,7.3 \%), f(1,1.2 \%), \text { non-typed } \\
(1,1.2 \%) .11 / 14(78.6 \%) \text { subjects were infected by a single } \\
\text { serotype, } 3 / 14(21.3 \&) \text { were infected by } 2 \text { serotypes. }\end{array}$ & Serotype $\mathrm{c}$ is the dominant A.a. serotype. \\
\hline $\begin{array}{c}\text { Takada et al. } 2010 \\
\text { [42]/Japan }\end{array}$ & Serotype g of A.a. in a patient with periodontitis patient. & New serotype g was reported. \\
\hline $\begin{array}{l}\text { Skellart et al. } 2011 \\
\text { [43]/Greece }\end{array}$ & $\begin{array}{l}\text { No statistical differences were observed concerning the } \\
\text { distribution of serotypes among groups. Serotype c was more } \\
\text { pre-dominant within the periodontally diseased groups; no } \\
\text { JP2 clone. }\end{array}$ & $\begin{array}{l}\text { A.a. serotype } \mathrm{b} \text { was not statistically correlated with periodontal } \\
\text { disease. }\end{array}$ \\
\hline $\begin{array}{l}\text { Claesson et al. } 2011 \\
\text { [44]/Sweden }\end{array}$ & $\begin{array}{l}\text { JP2 clone (serotype b) was detected in samples from } 2 \text { of the } \\
\text { family members. }\end{array}$ & $\begin{array}{l}\text { Caucasian JP2 carriers exist and older subjects can carry the } \\
\text { JP2 clone of A.a.. }\end{array}$ \\
\hline $\begin{array}{c}\text { Pinheiro et al. } 2012 \\
\text { [45]/Brazil } \\
\end{array}$ & 26 A.a. isolates were classified into 6 serotypes(a -f). & $\begin{array}{l}\text { Two serotype b (7.7\%) from AgP patients, highly leukotoxic } \\
\text { genotype; c is the most prevalent. }\end{array}$ \\
\hline $\begin{array}{c}\text { Cortelli et al. } 2012 \\
\text { [46]/Brazil }\end{array}$ & $\begin{array}{l}204 \text { subjects with-A.a.-(+): single serotype (152), variable in- } \\
\text { fected (27), non-typed (25). Serotypes a, b, and c were largely } \\
\text { found (\%), and serotype c was the most prevalent, d-e-f were } \\
\text { not detected or rare. }\end{array}$ & $\begin{array}{l}\text { Serotype c was the most prevalent in both diseased and healthy } \\
\text { subjects. AgP subjects were not exclusively associated with A.a. } \\
\text { serotype b. }\end{array}$ \\
\hline
\end{tabular}




\begin{tabular}{|c|c|c|}
\hline $\begin{array}{l}\text { Jentsch et al. } 2012 \\
\text { [47]/German }\end{array}$ & $\begin{array}{l}99 \text { Subjects with A.a.-(+): a }(25,5.2 \%), \mathrm{b}(22,22.5 \% \text {, including } \\
2 \text { with JP2), c (21, 21.2\%), others and non-typed }\end{array}$ & $\begin{array}{l}\text { Results show that A.a. serotype are different. between the cities } \\
\text { and native and immigrants. }\end{array}$ \\
\hline $\begin{array}{l}\text { Bandhaya et al. } 2012 \\
\text { [48]/Thialand }\end{array}$ & $\begin{array}{l}\text { Serotype c (57\%) was the most prevalent, followed by a } \\
\qquad(33 \%) \text { and b }(7 \%) .\end{array}$ & $\begin{array}{l}\text { No significant relationship between serotypes and the extent or } \\
\text { severity of periodontal disease. }\end{array}$ \\
\hline $\begin{array}{l}\text { Brigido et al. } 2014 \\
\text { [49]/Review }\end{array}$ & $\begin{array}{l}\text { 12/85 studies met criteria: } a, b \text {, and c were largely found, c } \\
\text { was the most prevalent. }\end{array}$ & $\begin{array}{l}\text { Serotypes a, b, and c are globally dominant, serotypes } \mathrm{d} \text { and } \\
\text { e are rare, fis still unknown in distribution. Distribution } \\
\text { pattern of A.a. vary among subjects of different ethnicity and } \\
\text { geographic regions. The correlation of different serotypes with } \\
\text { periodontal conditions remains unclear. }\end{array}$ \\
\hline $\begin{array}{l}\text { Tsuzukibashi } 2014 \\
\text { [50]/Japan }\end{array}$ & $\begin{array}{l}\text { Serotype g of A.a. gene cluster and primers for serotyping } \\
\text { were reported. }\end{array}$ & $\begin{array}{l}\text { The specific primers derived from these different areas are } \\
\text { useful in identification and distribution of serotype g. among } \\
\text { A.a. from clinical samples. }\end{array}$ \\
\hline $\begin{array}{l}\text { Minguez et al. } 2014 \\
\text { [51]/Japan }\end{array}$ & $\begin{array}{l}\text { 40/701 (5.7\%) subjects with A.a.-(+): b (30 subjects), co-col- } \\
\text { onization (7 subjects, most are a and b). Among } 79 \text { isolates: a } \\
\text { (24), b (30), c(12), d (4), no JP2, 65.8\% were cdt+. }\end{array}$ & $\begin{array}{l}\text { The results show that the most common serotypes are a and } \\
\mathrm{b} \text { (b is the most prevalent in mono-colonization), e and f were } \\
\text { not detected. All isolates ( } 100 \%) \text { are with genes responsible for } \\
\text { the indication of leukotoxin. }\end{array}$ \\
\hline $\begin{array}{l}\text { Feng et al. } 2015 \\
{[52] / \text { China }}\end{array}$ & $62 \mathrm{AgP}$ patients and $45 \mathrm{HC}$ were analyzed. & $\begin{array}{l}\text { Serotype c was the main serotype of A.a. in Chinese patients } \\
\text { with AgP. }\end{array}$ \\
\hline $\begin{array}{l}\text { Pahumunto et al. } \\
2015 \text { [53]/Thailand }\end{array}$ & $\begin{array}{c}44 \text { CP patients yield } 79 \text { strains of A.a. from deep pockets, } \\
17 \text { strains from shallow pockets. } 84.1 \% \text { of A.a.-positive: } \\
\text { serotypes: a/18.2\%, c/5.9\%, e/9.1\%, f/11.4\%, no b and d, } \\
\text { non- typed/45.5\%. A JP2-like strain (530bp deletion, from } \\
2 \text { patients belong to serotype c) was found. } 2 \text { strains with } \\
\text { 886bp insertion on the Itx promoter. Most patients showed } \\
\text { only one serotype (32.4\%), } 29.7 \% \text { showed } 2 \text { and } 3 \text { different } \\
\text { serotypes. }\end{array}$ & $\begin{array}{c}\text { A greater subtype diversity of A.a. predominated by non-typed } \\
\text { strains than previously reported. Isolates with 530bp deletion } \\
\text { or } 886 \text { insertion of the Itx promoter were serotyped as sero- } \\
\text { type c. }\end{array}$ \\
\hline $\begin{array}{l}\text { Minguez et al. } 2016 \\
\text { [54]/Morocco }\end{array}$ & $\begin{array}{l}21 / 59(35.6 \%) \text { periodontitis patients were A.a.-positive. } 39 \\
\text { A.a. isolates were b serotype only, } 5 \text { isolates from } 2 \text { patients } \\
\text { (12.2\% of the strains were JP2-leukotoxin positive, } 78 \% \text { were } \\
\text { also cdt-positive. }\end{array}$ & A. $a$, can be frequently found in Morocco. \\
\hline $\begin{array}{l}\text { Joshi et al. } 2017 \\
\text { [55]/India }\end{array}$ & $\begin{array}{c}\text { Five serotypes: a (38.09\%), } 2 \text { serotypes ( } 36.5 \%), 3 \text { sero- } \\
\text { types (6.3\%), } 4 \text { serotypes ( } 4.7 \%) \text {, no JP2 strain. b (46.3\%), } \\
\text { c (36.5\%) and e (38.09\%) were the most serotypes. } 11 / 63 \\
\text { subjects with positive CMV, } 4 / 63 \text { with positive- EBV, 9/63 } \\
\text { with both viruses. }\end{array}$ & $\begin{array}{l}\text { The presence of multiple serotypes and a combination of any } \\
\text { serotype with herpesvirus is associated with greater severity } \\
\text { of the disease. }\end{array}$ \\
\hline $\begin{array}{l}\text { Claesson et al. } 2017 \\
\text { [56]/Sweden }\end{array}$ & $\begin{array}{l}\text { Younger patients }(</=35 \text { yrs. old) were with higher A.a.-pos- } \\
\text { itive frequency, b serotype was more prevalent. JP2 in } 1.2 \% \\
\text { (majority carriers were non-African origin). }\end{array}$ & $\begin{array}{l}\text { For presence and characteristics of A.a. in clinical samples the } \\
\text { age of the carriers were a discriminating factor. Non-African } \\
\text { carriers of the JP2 genotype of A.a. were identified. }\end{array}$ \\
\hline $\begin{array}{l}\text { Setty et al. } 2017 \\
\text { [57]/India }\end{array}$ & $\begin{array}{l}\text { 35/75 subjects ( } 25 \mathrm{AgP}, 25 \mathrm{CP}, 25 \mathrm{HC} \text { ), age from } 14-55 \mathrm{yrs} \text {. } \\
\text { old harbored A.a. ( } 46.66 \%) \text {. Serotypes: c }(19 / 35,54.28 \%), \mathrm{b} \\
\text { (non-alone), } 2 \text { samples were positive for both serotypes (b } \\
\text { and c, } 5.71 \%) \text {, non-typed }(14,40 \%) .\end{array}$ & $\begin{array}{l}\text { Serotype c was predominant in periodontal disease as well as } \\
\text { periodontal healthy individuals. Association could be present } \\
\text { between genotypes serotype and genotype-periodontal status. }\end{array}$ \\
\hline $\begin{array}{l}\text { Liu et al. } 2017[58] / \\
\text { Taiwan }\end{array}$ & $\begin{array}{l}\text { One hundred subjects: c serotype (22\%) and e (11\%) were } \\
\text { most common. }\end{array}$ & $\begin{array}{l}\text { A.a. strains with different serotypes are widely distributed in a } \\
\text { Taiwanese. }\end{array}$ \\
\hline
\end{tabular}




\begin{tabular}{|c|c|c|}
\hline $\begin{array}{l}\text { Akrivopoulou } 2017 \\
\qquad[59] / \mathrm{UK}\end{array}$ & $\begin{array}{c}\text { Serotypes: a ( } 48.6 \%) \text {, c }(22 \%) \text {, b ( } 2 \%) \text {, e }(2 \%) \text {, mixed sero- } \\
\text { types }(12 \%) \text {, and not typed }(7.14 \%) \text {. }\end{array}$ & $\begin{array}{l}\text { Resistance serotypes of A.a. were demonstrated. Antimicro- } \\
\text { bial susceptibility investigation in patients with AgP prior to } \\
\text { periodontal therapy. }\end{array}$ \\
\hline $\begin{array}{l}\text { Pietiannen et al. } \\
2018 \text { [60]/Finland }\end{array}$ & $\begin{array}{l}497 \text { patients underwent coronary angiography. A.a.-positive: c } \\
(35.7 \%), \mathrm{b}(28.6 \%) \text {, a }(26.2 \%) \text {, e (7.1\%), d (2.4\%), f (0\%). }\end{array}$ & $\begin{array}{l}\text { Serotype-positive subjects had less teeth, higher BoP. Serotype } \\
\text { b and c were associated with PPD and periodontal inflammato- } \\
\text { ry-burden. Serotype } \mathrm{c} \text { had the highest in saliva and subgingival } \\
\text { bacterium quantities and serum antibody levels against A.a.. } \\
\text { Serotypes b and c are the most frequent (59.3\%) in coronary } \\
\text { artery disease (CAD) patients associated with risk of stable } \\
\text { CAD, also associated with the severity of CAD. The results } \\
\text { suggest that A.a. serotypes b and c associate with periodontal } \\
\text { and CAD status. }\end{array}$ \\
\hline
\end{tabular}

\section{Discussion}

It is convinced that the differences in serotypes distribution related to geography and/or ethnic group. The current presented data indicate that the geographic distribution of serotypes is not uniform $[4,40,43,49]$. The distribution pattern of A.a. serotypes varies greatly depending on the periodontal status of the allocated population and the country where the study takes place [30,32,35 $, 40,43,45,47,49,52,53,58]$. Some studies suggest that different $A$.a. serotypes are associated with periodontal health, periodontitis $[6,10,15,18,31,34,39,49,52,57]$. It is suggested that patients are usually infected by one serotype and colonization is stable over time $[8,36,37]$, however occasional individuals are infected with two or three serotypes [34,37,39,40,44,47,52,545,57,59]. Most investigators found relatively low frequencies of multiple-serotype infection, except a study in Japan that shows 2 or 3 serotypes of A.a. with a frequency of $33 \%$ of the sites tested [31]. In general, the serotypes a-c occurred much more frequently among oral isolates than serotypes d-g. In African-Americans, a, b, and c serotypes seem to be distributed in equal frequencies, whereas in Hispanic subjects, a strong association with serotype c was reported [34]. In Greece [43], serotype a, b, and c were largely found to be equally distributed. In Brazilian population, the serotypes are in majority of a, b and c (up to 98\%), with the serotype c most prevalent. Serotypes $d, e$, and f were either rare or not-detected $[16,40,46]$. In 2010 Chen et al. [41] reported that the serotype $c$ is the dominant serotype followed by serotypes of $a$, and $b$, the $d$, e, and $f$ were either not detected or relatively rare in the United States [41]. This is greatly different from the previous reported.

Almost all the studies showed that the Asian populations were commonly infected with A.a. serotype c, but occasionally colonized with serotype b $[15,21,22,25-27,30,31,35-37,48,50-53,55,57,58]$. In Taiwan, two studies demonstrated that the c serotype was the predominant [21,58], other studies found that serotype $b$ was more than c or other serotypes [15,32]. In contrast, serotype b was commonly observed in Caucasian populations [37] and in German patients [37]. The serotype distribution pattern of $A$. $a$. within a local population may change over time, as seen in Indonesian periodontitis patients between 1994 to 2002 [36]. Serotypes d-f were rarely detected in most populations worldwide $[40,42,45]$, however, a high prevalence of serotype e (19-47\%) was noted in Indonesian [36] and Japanese [31]. JP2 (serotype b) strain with super-leukotoxicity was discovered in 1979 by the authors of Tsai et al. [61]. In Japan, serotype c was predominantly identified in the gingival tissues of LAgP patients [31], and the distribution of serotypes was influenced by the presence of $P$. gingivalis (P.g.). The longitudinal follow-up study in Indonesia demonstrated that the mean increase in probing pocket depth between 1994 and 2002 was significantly greater in subjects' culture positive in 2002 in comparison to subjects without detectable A. actinomycetemcomitans (A.a.) in 2002 [36]. The shifts of the predominant serotype $b$ to a more prevalence as evidenced by the studies in Indonesia and in the United States [41] might be explained to some extent, associated with the periodontal treatment including the use of antibiotics, and the high titer of antibody levels to predominant infected serotypes of A.a. The high levels of anti-A.a. antibody together with viable polymorphonuclear neutrophils (PMNs) and complement could more efficiently kill the infecting A.a. [62]. Thirdly, some previous studies classified serotype f as serotype $b$ due to the serological cross-reactivity with anti-serotype b-specific antiserum [29]. Fourthly, study has shown that the recombination between strains of the same A.a. serotype appears to take place in nature, suggesting that non-serotypeable strains are serotype antigen-deficient variants originating from strains of the known serotypes [63]. In Brazil, AgP subjects were not exclusively associated with A.a. serotype b [40,46]. Isolates from healthy subjects belong to serotype $\mathrm{c}$ or a [46]. Serotype c was the most A.a., and was isolated from various periodontal conditions, including AgP [45]. In Greek population, A.a. was more prevalent in untreated periodontitis subjects, but no clear predominance of a specific A.a. serotype and absence of the JP2 clone were observed [43]. In Sweden, the findings indicate that periodontitis affecting the primary dentition does not necessary leads to the presence of periodontal attachment loss in the permanent dentition [39].

The JP2 clone shows a limited geographical and ethnic host range, predisposing in subjects with an African lineage, but absent from non-African population from Northern Europe [14,65]. However, Claesson et al. [44] found that Caucasians can carry the JP2 clone of A. actinomycetemcomitans. The studies cited in this review have varied widely in periodontal disease diagnosis and status, sampling protocols, study design and microbial detection methods and serotype analysis techniques. The periodontal therapy aims to the elimination of A.a. from periodontal pockets has been shown to be correlated with the outcomes of therapy. Akrivopoulou et al. [59] studied the prevalence of A.a. serotypes and reported 
that of the 56 isolates tested, $100 \%$ were resistant to penicillin and metronidazole, $87.5 \%$ to clindamycin, $83.9 \%$ to amoxicillin and $76.8 \%$ to ceftazidime; low rates of resistance to tetracycline $(8.9 \%$ resistant) and 2013; 5:20320. http//dx.dol.org/10.3402/jom. v510.20320. amoxicillin/clavulanic acid (14.3\%); no isolates were resistant to ciprofloxacin.

In the study of the antibiotic resistance in human periimplantitis microbiota, Ramus et al. [64] reported that all six A.a. subject strains exhibited in vitro resistance to clindamycin, and five to doxycycline, whereas none were resistant in vitro to either amoxicillin, metronidazole or amoxicillin plus metronidazole [65]. However, adjunctive systemic amoxicillin plus metronidazole medication to scaling and root planing (SRP) significantly improved the clinical outcomes with respect to mean probing pocket depth, clinical attachment loss compared to SRP alone [66]. In contrast, Aggregatibacter actinomycetemcomitans JP2 homotypic biofilms were more susceptible in vitro to doxycycline than amoxicillin plus metronidazole [66]. Such results highlight the need for culture and antibiotic susceptibility tests in patients with aggressive periodontitis $(\mathrm{AgP})$ and patients with peri-implantitis prior to systemic use of antibiotics concomitantly to periodontal therapy. In conclusion, this review indicates that different ethnic groups are preferentially colonized by different $A$. actinimycetemcomitans serotypes and the relationship between $\operatorname{different}$ A.a. serotypes and periodontal conditions remains to be investigated in the future.

\section{Conflict of interest}

The authors declare that they have no conflict of interests related to this publication.

\section{References}

1. Armitage GC (1999) Development of a classification system for periodontal diseases and conditions. Ann Periodontol 4(1): 1-6.

2. Armitage GC (2004) Periodontal diagnoses and classification of periodontal diseases. Periodontol 2000 34: 9-21.

3. Pihlstrom BL, Michalowicz BS, Johnson NW (2005) Periodontal diseases. Lancet 366(9499): 1809-1820.

4. Fine DH, Markowitz K, Furgang D, Fairlie K, Ferrandiz J, et al. (2007) Aggregatibacter actinomycetemcomitans and its relationship to initiation of localized aggressive periodontitis: Longitudinal cohort study of initially healthy adolescents. J Clin Microbiol 45(12): 3859-3869.

5. Faveri M, Figueiredo LC, Duarte PM, Mestnik MJ, Mayer MP, et al. (2009) Microbiological profile of untreated subjects with localized aggressive periodontitis. J Clin Periodontol 36(9): 739-749.

6. Kaplan JB, Perry MB, MacLean LL, Furgang D, Wilson ME, et al. (2001) Structural and genetic analyses of 0 polysaccharide from Actinobacillus actinomycetemcomitans serotype f. Infect Immun 69(9): 5375-5384.

7. Tsuzukibashi O, Saito M, Kobavashi T, Umezawa K, Nagahama E, et al (2014) A gene cluster for the synthesis of serotype g-specific polysaccharide antigen in Aggregatibacter actinomycetemcomitans. Arch Microbiol 196(4): 261-265.

8. Zambon JJ, Slots J, Genco RJ (1983) Serology of oral Actinobacillus actinomycetemcomitans and serotype distribution in human periodontal disease. Infect Immun 41(1): 19-27.

9. Saarela M, Asikainen S, Alaluusua S, Pyhala L, Lai CH, et al. (1992) Frequency and stability of mono- or poly-infection by Actinobacillus actinomycetemcomitans serotypes a, b, c, d or e. Oral Microbiol Immunol
7(5): 277-279.

10. Asikainen S, Chen C, Slots J (1995) Actinobacillus actinomycetemcomitans genotypes in relation to serotypes and periodontal status. Oral Microbiol Immunol 10(2): 65-68.

11. Zambon JJ, Chritersson LA, Slots J (1983) Actinobacillus actinomycetemcomitans in human periodontal disease. Prevalence in patient groups and distribution of biotypes and serotypes within families. J Periodontol 54(12): 707-711.

12. Asikainen S, Chen C (1999) Oral ecology and person-to-person transmission of Actinobacillus actinomycetemcomitans and Porphyromonas gingivalis. Periodontol 2000 20: 65-81.

13. Rylev M, Kilian M (2008) Prevalence and distribution of principal periodontal pathogens worldwide. J Clin Periodontol 35(8 Suppl): 346-361.

14. Dahlén G, Widar F, Teanpaisan R, Papapanou PN, Baelum V, et al. (2002) Actinobacillus actinomycetemcomitans in a rural adult population in southern Thailand. Oral Microbiol Immunol 17(3): 137-142.

15. Yang HW, Huang YF, Chan Y, Chou MY (2005) Relationship of Actinobacillus actinomycetemcomitans serotypes to periodontal condition: Prevalence and proportions in subgingival plaque. Eur J Oral Sci 113(1): 28-33.

16. Teixeira RE, Mendes EN, Roque de Carvalho MA, Nicoli JR, Farias LM, et al. (2006) Actinobacillus actinomycetemcomitans serotype-specific genotypes and periodontal status in Brazilian subjects. Can J Microbiol 52(3): 182-188.

17. Asikainen S, Lai CH, Alaluusua S, Slots J (1991) Distribution of Actinobacillus actinomycetemcomitans serotypes in periodontal health and disease. Oral Microbiol Immunol 6(2): 115-118.

18. Haubek D, Dirienzo JM, Tinoco EM, Westergaard J, López NJ, et al. (1997) Racial tropism of a highly toxic clone of Actinobacillus actinomycetemcomitans associated with juvenile periodontitis. J Clin Microbiol 35(12): 3037-3042.

19. Tinoco EM, Lyngstadaas SP, Preus HR, Gjermo P (1997) Attachment loss and serum antibody levels against autologous and reference strains of Actinobacillus actinomycetemcomitans in untreated localized juvenile periodontitis patients. J Clin Periodontol 24(12): 937-944.

20.Zambon JJ (1985) Actinobacillus actinomycetemcomitans in human periodontal disease. J Clin Periodontol 12(1): 1-20.

21. Tsai CC, Chen CC, GJ Hou GL, KY Ho KY, YM Wu YM, et al. (1987) Serum antibody activity against Actinobacillus actinomycetemcomitans in Chinese patients with periodontitis. Gaoxiong Yi Xue Ke Xue Za Zhi 3(11): 714-722.

22. Chung HJ, Chung CP, Son SH, Nisengard RJ (1989) Actinobacillus actinomycetemcomitans serotypes and leukotoxicity in Koren juvenile periodontitis. J Periodontol 60(9): 506-511.

23. Asikalinen S, Lai CH, Alalunusua S, Slots J (1991) Distribution of Actinobacillus actinomycetemcomitans serotypes in periodontal health and disease. Oral Microbiol Immuno 6(2): 115-118.

24. Saarela M, ASikainen S, Alaluusua S, Pyhala L, Lai CH, et al. (1922) Frequency and stability of mono- $0 \mathrm{r}$ poly-infection by Actinobacillus actinomycetemcomitans serotypes a, b, c, d or e. Oral Microbiol Immunol (5): 277-279.

25. Yamamoto M, Nishihara T,Koseki T,He T,Yamato K, et al. (1997) Prevalence of Actinobacillus actinomycetemcomitans serotypes in Japanese patients with periodontitis. J Periodontal Res 32(8): 676-681.

26. Mombelli A, Gmur R, Frey J, Meyer J, Zee KY, et al. (1998) Actinobacillus actinomycetemcomitans and Porphyromonas gingivalis in young Chinese adults. Oral Microbiol Immunol 13(4): 231-237.

27. Mombelli, A, Gmur R, Lang NP,Corbert E, Frey J (1999) Actinobacillus actinomycetemcomitans in Chinese adults. Serotype distribution and analysis of leukotoxin gene promoter locus. J Clin Periodontol 26(8): 505-510. 
28. Saarela MH, Dogan B, Alaluusura S, Asikainen S (1999) Persistence of oral colonization by the same Actinobacillus actinomycetemcomitans strain(s). J Periodontol.

29. Kaplan JB, Perry MB, MacKean LL, Furgang D, Wilson ME, et al. (2001) Structure and genetic analysis of 0 polysaccharide from Actinobacillus actimycetemcomitans serotype f. Infect Immun 69(9): 5375-5384.

30. Dahlen G,Widar F,Teanpaissan R, Papapanou PN, Baelum V,et al. (2002) Actinobacillus actimycetemcomitans in a rural adult population in southern Thailand. Oral Microbiol Immunol 17(3): 137-142.

31. Yoshida Y, Suzuki N, Nakano Y, Shibuv K, Oqawa Y, et al. (2003) Distribution of Actinobacillus actinomycetemcomitans serotypes and Porphyromonas gingivalis in Japanese adults. Oral Microbiol Immuno 18(3): 135-139.

32. Yang HW, Asikainen S, Dogan B, Suda R, Lai CH (2004) Relationship of Actinobacillus actimycetemcomitans serotype b to AgP: frequency in pure cultured isolates. J Periodontol 75(4): 592-599.

33. Teixeira RE, Mendes EN, Roquede CMA, Nicolo JR, FariasLde M, et al. (2006) Actinobacillus actimycetemcomitans serotype-specific genotypes and periodontal status in Brazilian subjects. Can J Microbiol 52(3): 182-188.

34. Fine DH, Markowitz K, Furogang D, Fairlie K, Ferrandiz J, et al. (2007) Actinobacillus actimycetemcomitans and its relationship to initiation of LAgp: Longituidinal cohort study of initially healthy adolescents. J Clin Microbiol 45(12): 3859-3869.

35. Thiha K, Takeuchi Y,Umeda M, Huang Y,Ohnishi M, et al. (2007) Identification of periodontopathic bacteria in gingival tissue of Japanese periodontitis patients. Oral Microbiol Immunol 22(3): 201-207.

36. Van der Reijden WA, Bosch Tijhof CJ, van der Velden U, van Winkelhoff AJ (2008) Java projects on periodontal diseases: Serotype distribution of A>a. and serotype dynamics over an 8-year period. J Clin Periodontol 35(6): 487-492.

37. Kim TS, Frank P,Eickholz P,Erick S, Kim CK (2009) Serotypes of Actinobacillus actimycetemcomitans in patients with different ethnic backgrounds. J Periodontol 80(12): 2020-2027.

38. Kawamoto D, Ando ES, Longo PL, Nunes AC, Wikstrom M, et al. (2009) Genetic diversity and toxic activity of Actinobacillus actimycetemcomitans isolates. Oral Microbiol Immunol 24(6): 493-501.

39. Aberg CH, Sjödin B, Lakio L, Pussinen PJ, Johansson A, et al. (2009) Presence of Aggregatibacter actinomycetemcomitans in young individuals: A 16-year clinical and microbiological follow-up study. J Clin Periodontol 36(10): 815-822.

40. Roman Torres CV, Aquino DR, Cortelli SC, Franco GC, Dos Santos JG, et al. (2010) Prevalence and distribution of serotype-specific genotypes of Aggregatibacter actinomycetemcomitans in chronic periodontitis Brazilian subjects. Arch Oral Biol 55(3): 242-248.

41. Chen C, Wang T, Chen W (2010) Occurrence of Aggregatibacter actinomycetemcomitans serotypes in subgigival plaque from United States subjects. Mol Oral Microbioll 25(3): 207-214.

42. Takada K, Saito M, Tsuzukibashi O, Kawashima Y, Ishda S, et al. (2010) Characterization of a new serotype g isolate of Aggregatibacter actinomycetemcomitans. Mol Oral Microbil 25(3): 200-206.

43. Skellari D, Katsikari A, Slini T, Joannidis I, Konstantinidis A, et al. (2011) Prevalence and distribution of Aggregatibacter actinomycetemcomitans serotypes and the JP2 clone in a Greek population. J Clin Periodontol38(2): 108-114.

44. Claesson R, Lagervaill M, Johansson A, Haubek D, Aberg HC (2011) Detection of highly leukotoxic JP2 clone of Aggregatibacter actinomycetemcomitans in members of a Caucasan family living in Sweden. J Clin Periodontol 38(2): 115-121.

45. Pinheiro ET, Kawanmoto D, Ota Tsuzuki C, Almeida LR, Nunes AC, et al (2011) Analysis of genotypic variation in genes associated with virulence in Aggregatibacter actinomycetemcomitans clinical isolates. J Periodontal
Res 46(3): 310-317

46. Cortelli JR, Aquino DR, Cortelli SC, Roman Torres CV, Franco GC, et al. (2012) Aggregatibacter actinomycetemcomitans serotypes infections and periodontal conditions: A two-way assessement. Eur J Clin Microbiol Infect Dis 31(7): 1311-1318.

47. Jentsch H, Cachovan G, Guentsch A, Eickolz P,Pfister W, et al. (2012) Characterization of Aggregatibacter actinomycetemcomitans strains in periodontitis patients in Germany. Clin Oral Investig 16(6): 1589-1597.

48. Bandhava P,Sarithong P,Likittanasombat K, Hengprasith B, Torrungruang K (2012) Aggregatibacter actinomycetemcomitans serotypes, the JP2 clone and cytolethal distending toxin genes in a Thai population. J Clin Periodontol 39(6): 519-25.

49. Brigido JA, da Silveira VR, Rego RO, Nogueira NA (2014) Serotypes of Aggregatibacter actinomycetemcomitans in relation to periontal status and geographic origin of individuals-a review of the literature. Med Oral Pathol Oral Cir Bucal 19(2): e184-e191.

50. Tsuzukibashi O,Saito M, Kobavashi T, Umezawa K, Nagahama E, et al. (2014) A gene cluster for the synthesis of serotype g-specific polysaccharideantigen in A.a. Arch Microbiol 1964(4):261-265.

51. Minguez M, Poisa X, Herrena D, Biasi A, Sanchez MC, et al. (2014) Characterization and serotype distribution of Aggregatibacter actinomycetemcomitans isolates from a population of periodontitis patients in Spain. Arch Oral Biol 59(12): 1359-1367.

52. Feng XH, Zhang L, Xu L, Meng HX, Chen ZB, et al. (2015) Analysis of serum IgG titers to Aggregatibacter actinomycetemcomitans Serotype $c$ in aggressive periodontitis patients. Beljing Da Xue Xue Bao Yi Xue Ban 47(5): 820 824.

53. Pahumunto N, Ruangsri P,Wongsuwanlert M, Piwat S, Dahlen G,et al. (2015) Aggregatibacter actinomycetemcomitans serotypes and DGGE subtypes in Thai adults with CP.Arch Oral Biol 60(12): 1789-1796.

54. Minquez M, Ennibi OK, Pousa X, Lakhdar L, Abdellaoui L, et al. (2016) Characterization of Aggregatibacter actinomycetemcomitans strains in subgingival samples from periodontitis subjects in Morocco. Clin Oral Investigation 20(7): 1809-1818.

55. Joshi VM, Bhat KG, Kugaji MS, Shirahatti R (2017) Characterization and serotype distribution of Aggregatibacter actinomycetemcomitans: Relationship of serotypes to herpesvirus and periodontal status in Indian subjects. Microb Patholog 110: 189-195.

56. Claesson R, Hoglund Aberg C, Haubek D, Johansson A (2017) Age-related prevalence and characteristics of Aggregatibacter actinomycetemcomitans in periodontitis patients living in Sweden. J Oral Microbiol 9(1): 1334594.

57. Setty S, Wadikar T, Suprith SS, Bhat K, Thakur S (2017) Profiling of Aggregatibacter actinomycetemcomitans serotypes b and the genotypes in periodontal health and disease. Indian J Med Microbiol 35(4): 543-550.

58. Liu CC, Chen CH, Tang CY, Chen KH, Chen ZF, et al. (2017) Prevalence and comparative analysis of the type IV secretion system in Aggregatibacter actinomycetemcomitans. J Microbiol Immunol Infect 51(2): 278-285.

59. Akrivopoulou C, Green IM, Donos N, Nair SP, Ready D (2017) Aggregatibacter actinomycetemcomitans serotype prevalence and antibiotic resistance in a UK population with periodontitis. J Glob Antimicrob Resis 10: 54-58.

60. Pietiainen M, Kopra KAE, Vuorenkoski J, Salminen A, Paju S, et al. (2018) Aggregatibacter actinomycetemcomitans serotypes associate with periodontal and coronary artery disease status. J Clin Periodontol 45(4): 413421.

61. Tsai CC, McArthur WP, Baehni PC, Hammond BF, Taichman NS (1979) Extraction and partial characterization of a leukotoxin from a plaque-derived microorganism. Infect Immun 25(1): 427-439.

62. Wilson ME, Genco RJ (1989) The role of antibody, complement and neutrophils in host defense against Actinobacillus actinomycetemcomitans Immunol Invest 18(1-4): 187-209. 
63. Poulsen K, Theilade E, Lally ET, Demuth DR, Kilian M (1994) Population structure of Actinobacillus actinimycetemcomitans: A framework for disease-associated properties. Microbiology 140(Pt 8): 2049-2060.

64. Haraszthy VI, Hariharan G, Tinoco EM, Cortelli JR, Lally ET, et al. (2000) Evidence for the role of highly leukotoxic Actinobacillus actinomycetemcomitans in the pathogenesis of localized juvenile and other forms of early-onset periodontitis. J Periodontol 71(6): 912-922.

65. Ramus TE, Degener JE, van Winelhof AJ (2014) Antibiotic resistance in human peri-implantitis microbiota. Clin Oral Implants Res 25(1): 82-90.
66. Zanddbergen D, Slot DE, Niederman R, van der Weijden F (2016) The concomitant administration of systemic amoxicillin and metronidazole compared to scaling and root planing alone in treating periodontitis: A systemic review. BMC Oral Health 16: 27.

67. Oettinger Barak O, Dashper SG, Catmill DV, Adams GG, Sela MN, et al. (2013) Antibiotic susceptibility of Aggregatibacter actinomycetemcomitans JP2 in a biofilm. J Oral Microbiol 5. 